\title{
IMPACT OF FERTILIZATION BY USING SOME PHENOLIC COMPOUNDS AND HUMIC ACID ON MARJORAM PLANTS SUSCEPTIBILITY TO INSECTS AND MITE INFESTATION AND PLANT FEATURES
}

\author{
HAMMAM, K. A. ${ }^{1}$; AFAF M. S. EL-ROBY ${ }^{2}$ and MONA I. AMMAR ${ }^{2}$ \\ 1 Medicinal and Aromatic Plant Research Department Horticulture Research Institute, ARC \\ 2 Plant Protection Research Institute, ARC.
}

(Manuscript received 16 April 2019)

\begin{abstract}
$\mathrm{P}$ resent study was conducted in the seasons of 2017 and 2018 at the Central Laboratory for Agriculture Climate, Agriculture Research Center (ARC), Dokki, Giza., to investigate the influence of some phenolic chelate compounds (Humic acid, Potassium benzoate and Salicylic acid) in three levels (1.0gm., $1.5 \mathrm{gm}$. and $2.0 \mathrm{gm}$. /L) on the susceptibility of marjoram plants to the infection with Aphis gossypii Glover, Thrips tabaci Lind., and Tetranychus urticae Koch as well as yield, growth features and essential oil contents. The results proved that the using of $2.0 \mathrm{gm} . / \mathrm{L}$ of salicylic acid, potassium benzoate and humic acid as fertilizers to marjoram plants, caused highly significant infestation reduction of target pests' as well as the effects on the growth characteristics in the first and second cuts in both seasons. Resulted in an increasing number of branches per plant in addition increased plant height, also, it caused significantly increasing in fresh and dry weights. The highest oil yield / plant were obtained with applying salicylic acid at $2.0 \mathrm{~g} / \mathrm{L}$. Leaf area $\left(\mathrm{cm}^{2}\right)$ of marjoram was increased by different foliar spraying by humic acid and salicylic acid in the $1^{\text {st }}$ and $2^{\text {nd }}$ cut of both seasons. Foliar application of potassium benzoate gave poor results in this concern.

Key Words: Marjoram, insects and mite, vegetative growth and yield, essential oil, phenolic chelate compounds, Aphis gossypii, Thrips tabaci (Koch), and Tetranychus urticae.
\end{abstract}

\section{INTRODUCTION}

Marjoram (Majorana hortensis, L) is a perennial herbaceous plant belonging to Lamiaceae family. It is one of the most commercially important medicinal plants. Marjoram is an important aromatic and medicinal plant. It has been cultivated in the Mediterranean countries and is still widely cultivated today. The active principles are found chiefly in the aerial parts (Majorana) herb. In Egypt, it is considered as an important economic agricultural export crop (Demetzos and Perdetzoglo, (2001). The major components of marjoram oil are a-Pinene, $\beta$-Pinene, limonene, 1.8 cineole, linalool, terpinene-4-ol, a-Terpinene, Linalyl acetate and eugenol, some of these components are used for scenting cosmetics and others are used for flavoring pharmaceuticals such as D-limonene and Linalool (Ostas et al., 2001). 
Plant phenolics are generally thought to play significant roles in plant defense against herbivores and pathogens. Many plant taxa are rich in phenolic compounds and some insect herbivores have been shown to acquire phenolics from their hosts to use them as protection against their natural enemies Marta et al., (2013). The environmental problems caused by overuse of pesticides have been the matter of concern for both scientists and public in recent years. The extensive use of the synthetic insecticides lead to the biological imbalance due to the destruction of beneficial species such as parasites and predators of the pests beside the destruction of pollinating insects Koul et al., (2008). Natural products of plants and plant derivatives are alternative agent to currently use for insect control because they constitute rich sources of bioactive chemicals. They are often active against insect species. They are biodegradable to non-toxic products, so that many investigators initiated large screening efforts poisonous effects to use them as insecticides (ElShazly and Hussien, 2004 and Prows et al., 2006). Humic acid could be used as organic fertilizer and growth regulator to adjusted hormone level, for plant growth improvement and enhance stress tolerance along with increasing shoot and root growth (Nardi et al., 2002). Said-Al Ahl et al., (2016) indicated that plant height, number of branches and oil \% of dill increased significantly with humic acid. Khazaie et al., (2011) humic acid showed great influence on vegetative growth, leaf biomass and essential oil production. Humic acid at $300 \mathrm{ml} / \mathrm{L}$ resulted in highest amounts of aboveground, leaf biomass and essential oil production compared to untreated plants. Serafimov and Golubinova (2015) noticed that, seedling length reduction was the greatest when potassium sorbate was used on Lactuca sativa L. El-Khateeb et al., (2010) on Calia secundiflora plants stated that foliar application of humic acid had a significant effect of $\mathrm{N}, \mathrm{P}$ and $\mathrm{K}$ contents of herb compared with control.

It has also been reported that, salicylic acid enhances plant resistance against biological and antibiotic stresses Sawada et al., (2006). It is confirmed that salicylic acid reduces accumulation and leakage of toxic ions in plants (Krantev, et al., (2008) and Zhou et al., (2009). Stevens and Senaratna (2006) it has been reported that salicylic acid significantly enhances the average growth speed of tomato stems in 200 Mm. Bayat et al., (2012) revealed that, exogenous application of salicylic acid enhanced shoot, fresh and dry weights in Calendula officinalis. Abdol Rahman et al., (2013) indicated that the lowest concentrations of salicylic acid (0.01 and $0.1 \mathrm{mM}$ ) resulted significantly increased of plant height, number of branches and essential oil yield of cumin.

Therefore, this research was carried out to study the effects of the foliar spraying application of phenolic chelate compounds on the population of four Insects 
\& mite infestation on marjoram (Majorana hortensis $\mathrm{L}$ ) and plants growth, oil yield and chemical composition.

\section{MATERIALS AND METHODS}

\section{1- Methodology:}

This experiment was conducted at Central Laboratory for Agriculture Climate, Agriculture Research Center (ARC), in the seasons of 2017 and 2018 in Giza Governorate, to investigate the impact of using some phenolic chelate compounds and humic acid as foliar spraying on marjoram plants on vegetative growth parameters and chemical composition on two insects pests and mite infesting marjoram plants; Aphis gossypii Glover, Thrips tabaci Lind. and Tetranychus urticae (Koch). Potassium benzoate, salicylic acid and humic acid treatments with different concentrations applied as foliage application, the experiment was designed in randomized complete block with 10 treatments and 3 replicates as follow:

1- Control was sprayed with water.

2- Humic acid (HA) $1.00 \mathrm{gm} / \mathrm{L}$.

3- Humic acid (HA) $1.50 \mathrm{gm} / \mathrm{L}$.

4- Humic acid (HA) $2.00 \mathrm{gm} / \mathrm{L}$.

5- Potassium benzoate (PB) $1.00 \mathrm{gm} / \mathrm{L}$.

6- Potassium benzoate (PB) $1.50 \mathrm{gm} / \mathrm{L}$.

7- Potassium benzoate (PB) $2.00 \mathrm{gm} / \mathrm{L}$.

8- Salicylic acid (SA) $1.00 \mathrm{gm} / \mathrm{L}$.

9- Salicylic acid (SA) $1.50 \mathrm{gm} / \mathrm{L}$

10- Salicylic acid (SA) $2.00 \mathrm{gm} / \mathrm{L}$

\section{Plant materials}

Marjoram seedlings (about $15 \mathrm{~cm}$ in height) were obtained from the farm of ElKanater El- Khayria. Horticulture Research Institute, ARC. Seedlings were sown on $23^{\text {rd }}$ and $25^{\text {th }}$ March in the first and second seasons respectively, at spacing of $(60 \times 25)$ $\mathrm{cm}$ during both seasons on one side of the row. The experiment plots were $3.0 \times 2.0$ meters, with three rows at distance of $60 \mathrm{~cm}$ between rows.

\section{Effect of treatments on some insects and mite infestation:}

Phenolic chelate compounds and humic acid sprays in suggested doses were applied on seedlings at one week after germination at 7 days intervals until transplanting. Under field conditions, treatments were applied at 10 days intervals from transplanting date until the flowering stage except the control treatment. Ten leaves were randomly taken /replicate/ week and put into paper bag then tightly 
closed and transferred to the laboratory to be inspected for counting insect and mites individuals by using Stereomicroscope:

- Number of Aphis gossypii, individuals /10 leaves.

- Number of Thrips tabaci. Individuals /10 leaves.

- Number of spider mite Tetranychus urticae movable stages /10 leaves.

II- Growth measurements:

The plants were harvested 2 times ( $1^{\text {st }}$ and $2^{\text {nd }}$ cut) on $14^{\text {th }}$ June and $17^{\text {th }}$ August for the two seasons 2017 and 2018 during the growing season by cut the plants and left $10 \mathrm{~cm}$ above the soil, and the different vegetative growth parameters were recorded in both seasons as follows: plant height $(\mathrm{cm})$, number of branches/ plant, leaf area $\left(\mathrm{cm}^{2}\right)$ was measured using CI-203 Handheld Laser Leaf Area Meter (CID, Bioscience) in Central Laboratory for Agricultural Climate, fresh and dry weight of herb / plant (gm), oil \% and oil yield / plant $\mathrm{ml} / \mathrm{L}$.

\section{III- Chemicals composition:}

\section{Nitrogen, phosphorus and potassium contents:}

Nitrogen, phosphorus and potassium were determined as dry weight basis according to the methods described by Bremner and Mulvaney (1982), Olsen and Sommers (1982) and Jackson (1970). While, essential oil \% in marjoram dry herb was determined according to British Pharmacopoeia (2002).

\section{Essential oil composition:}

The Gas Liquid Chromatography analysis (GLC) was used to analyze the essential oil samples and carried out in Laboratory of Medicinal and Aromatic Plants Research Department, Horticulture Research Institute, (HRI). (ARC) using Ds Chrom 6200 Gas Chromatograph apparatus was fitted with capillary column BPX-5, 5 phenyl (equiv.) polysillphenylene-siloxane $30 \times 0.25 \mathrm{~mm}$ ID $\times 0.25 \mu$ film. Temperature program ramp increase with a rate of $10^{\circ} \mathrm{C} / \mathrm{min}$ from $70^{\circ}$ to $200^{\circ} \mathrm{C}$. Flow rates of gases were nitrogen at $1 \mathrm{ml} / \mathrm{min}$, hydrogen at $30 \mathrm{ml} / \mathrm{min}$ and $330 \mathrm{ml} / \mathrm{min}$ for air Detector and injector temperatures were $300{ }^{\circ} \mathrm{C}$ and $250{ }^{\circ} \mathrm{C}$ respectively. The obtained chromatogram and report at GC analysis for each sample were analyzed to calculate the percentage of main components of the volatile oil according to Guenther and Joseph (1978).

\section{IV- Statistical analysis:}

- This experiment was designed as complete randomized block design. The experiment included 10 treatments and 3 replicates as described by Gomez and Gomez (1984). The percentages of infestation reduction were calculated according to SchneiderOrelli's formula (Nakano et al., (1981). 


$$
\text { Corrected } \%=\left(\frac{\text { Mortality } \% \text { in treated plot }- \text { Mortality } \% \text { in control plot }}{100-\text { Mortality \% in control plot }}\right) * 100
$$

Final data were analysis of variance (ANOVA) was performed on infesting pest and different treatments by (SAS, 1999) and appropriate error terms for the $\mathrm{F}$ tests of interactions were calculated separately. Comparisons of means were performed using the Duncan's multiple range test $(=0.05)$. Statistical analysis for horticulture was done by using the computer program MS-TATEC software version (4).

\section{RESULTS AND DISCUSSION}

\section{Effect of different tested treatments:}

Data in (Tables 1\&2) indicated the gradual reduction percentages of pests Aphis gossypii, Thrips tabaci and Tetranychus urticae numbers as a result of some phenolic chelate compounds and humic acid as foliar spraying on marjoram plants in both seasons 2017- 2018. Data showed highly significant differences between the three compounds with different concentrations.

\section{$I$.1 in first season:-}

\section{I.1.1 Aphis gosspyii}

Data shown in Table (1) throughout the first cut of marjoram plant indicated that salicylic acid treatment with the different concentrations used (2.0, 1.5 and 1.0 $\mathrm{g} / \mathrm{L}$ of water) gave highest reduction percentages against $A$. gosspyii being $(6.53,7.86$ and $7.90 \%$ ), respectively. The same results were achieved that in the second cuts with reduction percentages of $A$. gosspyii being $(8.33,8.66$ and $10 \%)$ in tested concentrations, respectively. While, potassium benzoate treatments $(2.0,1.5$ and $1.0 \mathrm{~g} / \mathrm{L})$ caused the intermediate efficacy, being $(8.2,8.8$ and $11.56 \%)$, respectively. Finally, humic acid treatments with the tested concentration caused the lowest reduction percentages of $A$. gosspyii (12.43, 13.3 and 15.9\%), respectively. In the second cut, treatments (Humic acid and Potassium benzoate) may arranged discerningly as $(11.33,15.66,16,21.66,21.33$ and 26\%) for the used tested concentrations $(2.0,1.5$ and $1.0 \mathrm{~g} / \mathrm{L})$, respectively, compared with control.

\section{I.1.2- Thrips tabaci}

Data shown in Table (1) throughout the first cut of marjoram plant indicated that salicylic acid treatment with the different concentrations used (2.0, 1.5 and 1.0 $\mathrm{g} / \mathrm{L}$ of water) gave highest reduction percentages against $T$. tabaci being $(0.50,0.63$ and $0.67 \%$ ), respectively. The same results were achieved that in the second cut with reduction percentages of $T$. tabaci being $(9.00,10.66$ and $12.66 \%)$ in tested concentrations, respectively. While, potassium benzoate treatments $(2.0,1.5$ and 
$1.0 \mathrm{~g} / \mathrm{L})$ caused the intermediate efficacy, being $(0.7,0.766$ and $0.97 \%)$, respectively. Finally, humic acid treatments with the tested concentration caused the lowest reduction percentages of $T$. tabaci $(1.1,1.33$ and $1.73 \%)$, respectively. In the second cut, treatments (Potassium benzoate and Humic acid) may arranged dissentingly as $(13.66,10.33,12.33,14.66,18.66$ and $19.66 \%)$ for the used tested concentrations $(2.0,1.5$ and $1.0 \mathrm{~g} / \mathrm{L})$, respectively, compared with control.

\section{I.1.3- Tetranychus urticae}

Data shown in Table (1) throughout the first cut of marjoram plant indicated that salicylic acid treatment with the different concentrations used (2.0, 1.5 and 1.0 $\mathrm{g} / \mathrm{L}$ of water) gave highest reduction percentages against $T$. urticae being $(0.8,1$ and $1.2 \%)$, respectively. The same results were achieved that in the second cut with reduction percentages of $T$. urticae being $(7.33,8.33$ and $9.33 \%)$ in tested concentrations, respectively. While, potassium benzoate treatments $(2.0,1.5$ and $1.0 \mathrm{~g} / \mathrm{L})$ caused the intermediate efficacy, being $(1.57,1.6$ and $1.90 \%)$, respectively. Finally, humic acid treatments with the tested concentration caused the lowest reduction percentages of $T$. urticae $(1.37,1.67$ and $1.67 \%)$, respectively, compared with in control. In the second cut, treatments (Potassium benzoate and Humic acid) may arranged descending as (15.33, 15.66, 16.33, 15.66, 16 and 19\%) for the used tested concentrations $(2.0,1.5$ and $1.0 \mathrm{~g} / \mathrm{L})$, respectively, compared with control.

These results are agreement with Bodenhausen, (2007) revealed that the foliar application of potassium benzoate and salicylic acid reduced the infestation numbers of T. urticae, T. tabaci, A. ipsilon and A.gosspyii in comparison numbers with the corresponding untreated treatments with humic acid in the first season 2017.

Table 1. Effect of using some phenolic chelate compounds on the reduction of insects and mite on marjoram (Majorana hortensis L) plants during two growth intervals in 2017.

\begin{tabular}{|c|c|c|c|c|c|c|}
\hline \multirow{3}{*}{ Treatments } & \multicolumn{6}{|c|}{ Reduction of pests } \\
\hline & \multicolumn{2}{|c|}{ Aphis gosspyii } & \multicolumn{2}{|c|}{ Thrips tabaci } & \multicolumn{2}{|c|}{ Tetranychus urticae } \\
\hline & $1^{\text {st }}$ cut & $2^{\text {nd }}$ cut & $1^{\text {st }}$ cut & $2^{\text {nd }}$ cut & $1^{\text {st }}$ cut & $2^{\text {nd }}$ cut \\
\hline Humic acid $1.00 \mathrm{~g} / \mathrm{L}$ & $15.90 \mathrm{a}$ & $11.33 \mathrm{~d}$ & $1.73 \mathrm{a}$ & $19.66 \mathrm{a}$ & $1.67 \mathrm{a}$ & $19.00 \mathrm{a}$ \\
\hline Humic acid $1.5 \mathrm{~g} / \mathrm{L}$ & $13.30 \mathrm{~b}$ & $15.66 \mathrm{c}$ & $1.33 a b$ & $18.66 \mathrm{ab}$ & $1.67 \mathrm{a}$ & $16.00 \mathrm{a}$ \\
\hline Humic acid $2.0 \mathrm{~g} / \mathrm{L}$ & $12.43 \mathrm{bc}$ & $16.00 \mathrm{c}$ & $1.1 \mathrm{bc}$ & $14.66 \mathrm{abc}$ & $1.37 \mathrm{~b}$ & $15.66 \mathrm{a}$ \\
\hline Potassium benzoate $1.0 \mathrm{~g} / \mathrm{L}$ & $11.56 \mathrm{c}$ & $26.00 \mathrm{a}$ & $0.97 \mathrm{~cd}$ & $12.33 \mathrm{cde}$ & $1.90 \mathrm{a}$ & $15.33 \mathrm{a}$ \\
\hline Potassium benzoate $1.5 \mathrm{~g} / \mathrm{L}$ & $8.80 \mathrm{~d}$ & $21.30 \mathrm{~b}$ & $0.77 \mathrm{~cd}$ & 10.33 de & $1.60 \mathrm{a}$ & $16.33 \mathrm{a}$ \\
\hline Potassium benzoate $2.0 \mathrm{~g} / \mathrm{L}$ & $8.20 \mathrm{~d}$ & $21.6 \mathrm{~b}$ & 0.70 cde & $13.66 \mathrm{bc}$ & $1.57 \mathrm{a}$ & $15.66 \mathrm{a}$ \\
\hline Salicylic acid $1.00 \mathrm{~g} / \mathrm{L}$ & $7.90 \mathrm{de}$ & $10.00 \mathrm{e}$ & $0.67 \mathrm{e}$ & $12.66 \mathrm{bcd}$ & $1.20 b c$ & $9.33 b$ \\
\hline Salicylic acid $1.5 \mathrm{~g} / \mathrm{L}$ & $7.86 \mathrm{de}$ & $8.66 \mathrm{e}$ & $0.63 \mathrm{de}$ & 10.66 de & $1.00 \mathrm{bc}$ & $8.33 b$ \\
\hline Salicylic acid $2.0 \mathrm{~g} / \mathrm{L}$ & $6.53 \mathrm{e}$ & $8.33 \mathrm{e}$ & $0.50 \mathrm{e}$ & $9.00 \mathrm{e}$ & $0.80 \mathrm{C}$ & $7.33 b$ \\
\hline F value & $74.81^{* * *}$ & $56.21 * * *$ & $9.03^{* * *}$ & $6.32 * * *$ & $8.70 * * *$ & $14.22 * * *$ \\
\hline LSD at: 0.05 & 1.01 & 0.25 & 0.41 & 0.47 & 0.36 & 0.34 \\
\hline
\end{tabular}




\section{I.2- second season:}

\section{I.2.1 Aphis gosspyii}

Data shown in Table (2) throughout the first cut of marjoram plant indicated that salicylic acid treatment with the different concentrations used $(2.0,1.5$ and $1.0 \mathrm{~g} / \mathrm{L}$ of water) gave highest reduction percentages against $A$. gosspyii being $(5.13,7.8$ and $8.6 \%)$, respectively. The same results achieved that in the second cuts with reduction percentages of $A$. gosspyii being (25.00, 29.00 and $31.33 \%$ ) in tested concentrations, respectively. While, humic acid treatments $(2.0,1.5$ and $1.0 \mathrm{~g} / \mathrm{L}$ ) caused the intermediate efficacy, being (7.53, 8.6 and $9.70 \%)$, respectively. Finally, potassium benzoate treatments with the tested concentration caused the lowest reduction percentages of $A$. gosspyii $(7.80,8.63$ and $10.76 \%$ ), respectively, compared red with in control. In the second cut, treatments (Humic acid and Potassium benzoate) may arranged discerningly as (12.33, 24, 42.66, $22.33,43.33$ and $35.33 \%)$ for the used tested concentrations $(2.0,1.5$ and $1.0 \mathrm{~g} / \mathrm{L})$, respectively, compared with control.

\section{I.2.2- Thrips tabaci}

Data shown in Table (2) throughout the first cut of marjoram plant indicated that salicylic acid treatment with the different concentrations used $(2.0,1.5$ and $1.0 \mathrm{~g} / \mathrm{L}$ of water) gave highest reduction percentages against $T$. tabaci being $(0.43,0.6$ and $0.8 \%)$, respectively. The same results achieved that in the second cuts with reduction percentages of $T$. tabaci being $(1.33,2.66$ and $3.66 \%)$ in tested concentrations, respectively. While, humic acid treatments $(2.0,1.5$ and $1.0 \mathrm{~g} / \mathrm{L})$ caused the intermediate efficacy, being $(1.1$, 1.2 and $1.4 \%)$, respectively. Finally, potassium benzoate treatments with the tested concentration caused the lowest reduction percentages of $T$. tabaci $(2.53,1.33$ and $1.83 \%$ ), respectively, compared with control. In the second cut, treatments (Humic acid and Potassium benzoate) may arranged dissentingly as (5.33, 6.00, 7.00, 6.33, 8.33 and $10.00 \%)$ for the used tested concentrations $(2.0,1.5$ and $1.0 \mathrm{~g} / \mathrm{L})$, respectively, compared with control.

Table 2. Effect of using some phenolic chelate compounds on the reduction of insects and mite on marjoram (Majorana hortensis $\mathrm{L}$ ) plants during two growth intervals in 2018.

\begin{tabular}{|l||c|c|c|c|c|c|}
\hline \hline \multirow{2}{*}{\multicolumn{1}{|c||}{ Treatments }} & \multicolumn{6}{c|}{ Reduction of pests } \\
\cline { 2 - 7 } & \multicolumn{2}{|c|}{ Aphis gosspyii } & \multicolumn{2}{c|}{ Thrips tabaci } & \multicolumn{2}{c|}{ Tetranychus urticae } \\
\cline { 2 - 7 } & $1^{\text {st }} \mathrm{cut}$ & $2^{\text {nd }} \mathrm{cut}$ & $1^{\text {st }} \mathrm{cut}$ & $2^{\text {nd }} \mathrm{cut}$ & $1^{\text {st }} \mathrm{cut}$ & $2^{\text {nd }}$ cut \\
\hline \hline Humic acid $1.0 \mathrm{~g} / \mathrm{L}$ & $9.70 \mathrm{~b}$ & $42.66 \mathrm{a}$ & $1.40 \mathrm{cb}$ & $7.00 \mathrm{c}$ & $2.20 \mathrm{a}$ & $25.33 \mathrm{a}$ \\
\hline Humic acid $1.5 \mathrm{~g} / \mathrm{L}$ & $8.60 \mathrm{c}$ & $24.00 \mathrm{e}$ & $1.20 \mathrm{~cd}$ & $6.00 \mathrm{~d}$ & $2.06 \mathrm{~b}$ & $19.33 \mathrm{~b}$ \\
\hline Humic acid $2.0 \mathrm{~g} / \mathrm{L}$ & $7.53 \mathrm{~d}$ & $12.33 \mathrm{f}$ & $1.10 \mathrm{de}$ & $5.33 \mathrm{e}$ & $1.23 \mathrm{~cd}$ & $17.00 \mathrm{~b}$ \\
\hline \hline Potassium benzoate $1.00 \mathrm{~g} / \mathrm{L}$ & $10.76 \mathrm{a}$ & $35.33 \mathrm{~b}$ & $1.83 \mathrm{~b}$ & $10.00 \mathrm{a}$ & $1.56 \mathrm{c}$ & $25.33 \mathrm{a}$ \\
\hline \hline Potassium benzoate $1.5 \mathrm{~g} / \mathrm{L}$ & $8.63 \mathrm{c}$ & $43.33 \mathrm{a}$ & $1.33 \mathrm{c}$ & $8.33 \mathrm{~b}$ & $1.40 \mathrm{c}$ & $24.00 \mathrm{a}$ \\
\hline \hline Potassium benzoate $2.0 \mathrm{~g} / \mathrm{L}$ & $7.80 \mathrm{~d}$ & $22.33 \mathrm{e}$ & $2.53 \mathrm{a}$ & $6.33 \mathrm{~cd}$ & $0.96 \mathrm{de}$ & $20.00 \mathrm{~b}$ \\
\hline \hline Salicylic acid $1.00 \mathrm{~g} / \mathrm{L}$ & $8.60 \mathrm{c}$ & $31.33 \mathrm{c}$ & $0.8 \mathrm{ef}$ & $3.66 \mathrm{f}$ & $1.23 \mathrm{~cd}$ & $11.33 \mathrm{c}$ \\
\hline \hline Salicylic acid $1.5 \mathrm{~g} / \mathrm{L}$ & $7.80 \mathrm{~d}$ & $29.00 \mathrm{dc}$ & $0.6 \mathrm{gf}$ & $2.66 \mathrm{~g}$ & $0.86 \mathrm{de}$ & $10.00 \mathrm{c}$ \\
\hline \hline Salicylic acid $2.0 \mathrm{~g} / \mathrm{L}$ & $5.13 \mathrm{e}$ & $25.00 \mathrm{de}$ & $0.43 \mathrm{~g}$ & $1.33 \mathrm{~h}$ & $0.43 \mathrm{e}$ & $8.60 \mathrm{c}$ \\
\hline \hline F value & $122.94 * * *$ & $83.91 * * *$ & $30.01^{* * *}$ & $9.51^{* * *}$ & $19.39 * * *$ & $37.32 * * *$ \\
\hline \hline LSD at: 0.05 & 0.42 & 0.31 & 0.33 & 0.27 & 0.35 & 0.34 \\
\hline
\end{tabular}




\section{I.1.3- Tetranychus urticae}

Data shown in Table (2) throughout the first cut of marjoram plant indicated that salicylic acid treatment with the different concentrations used (2.0, 1.5 and 1.0 $\mathrm{g} / \mathrm{L}$ of water) gave highest reduction percentages against $T$. urticae being $(0.43,0.86$ and $1.23 \%)$, respectively. The same results were achieved that in the second cuts with reduction percentages of $T$. urticae being $(8.60,10.00$ and $11.33 \%)$ in tested concentrations, respectively. While, potassium benzoate treatments in two tested cuts caused the intermediate efficacy, being $(0.96,1.40$ and $1.56 \%),(1.57 \%, 1.60 \%$ and $1.9 \%)$, respectively. Finally, humic acid treatments with the tested concentration caused the lowest reduction percentages of $T$. urticae $(1.23,2.06$ and $2.2 \%)$, respectively. In the second cut $T$. urticae being (17, 19.33 and $25.33 \%)$, respectively. compared with control.

Population' densities in 2017 was less at 1st cut than the 2nd cut. The second season was the opposite of the first season. These results are in agreement with Mahmoud and Mahfouz (2015) results that revealed the foliar spray application of humic acid and salicylic acid reduced the As soon as (Pettersson et al., (1994) reported that cereal crops treated with a slow release formulation of methyl salicylate had been avoided by many insects, (Pickett et al., 2006) showed that salicylic acid caused a reduction in aphid population within five weeks after application.

\section{Vegetative growth:}

\section{II.1 Plant height and number of branches/plant:-}

Data shown in table (3) represent the effect of humic acid, potassium benzoate and salicylic acid at 1.00, 1.5 and $2.0 \mathrm{~g} / \mathrm{L}$ treatments on vegetative growth characteristics of marjoram (Majorana hortensis $\mathrm{L}$ ). Both plant height and number of branches/plant were significantly increased in the most treatments of foliar fertilization compared with the untreated plants (control). The highest plant elongation's being $(54.31$ and $45.34 \mathrm{~cm})$ and $(53.78$ and $46.21 \mathrm{~cm})$ were recorded for the plants received humic acid at the highest rate of foliar fertilization; $(2.0 \mathrm{~g} / \mathrm{L})$ in the $1^{\text {st }}$ and $2^{\text {nd }}$ cut in both seasons respectively, followed by $(51.34$ and $43.57 \mathrm{~cm})$ and (52.65 and $44.31 \mathrm{~cm}$ ) were obtained with plants received salicylic acid at $2.0 \mathrm{~g} / \mathrm{L}$ at both cuts in the two seasons, respectively. Whereas, foliar fertilization of potassium benzoate resulted the least values compared with $\mathrm{Ha}$ and SA. Low plant elongation by using potassium benzoate by concentration $(2 \mathrm{~g} / \mathrm{L}$.) as foliar fertilization agrees with those of Serafimov, and Golubinova (2015) on Lactuca sativa L.

On the other hand, the results presented in Tables (3) also, indicated that the highest values from number of branches/plant (17.85, 16.35 and 13.75) and (39.25, 34.17 and 31.84 ) were obtained from humic acid, potassium benzoate and salicylic 
acid at $2.0 \mathrm{~g} / \mathrm{L}$ in the $1^{\text {st }}$ and $2^{\text {nd }}$ cuts in the first season, respectively compared with control (11.20 and 21.54) of two cuts in the first season, respectively. In the second season, data indicated the similar trend had been obtained as in the first one. Also, the results show that the humic acid had the superior effect on plant height and number of branches per plant. It is known that, humic acid used for plant nutrition, enhance root, plant growth and development as well as yield due to its action on physiological and metabolic processes Eyheraguibe et al., (2008). The present results come in agreement with Said-Al Ahl et al., (2016) on dill plants.

Table 3. Effect of using some phenolic chelate compounds on plant height, numbers of branches/plant and leaf area $\left(\mathrm{cm}^{2}\right)$ of marjoram (Majorana hortensis $\mathrm{L}$ ) plants of two cuts during two seasons 2017 and 2018.

\begin{tabular}{|c|c|c|c|c|c|c|}
\hline \multirow{3}{*}{ Treatments } & \multicolumn{6}{|c|}{ First season 2017} \\
\hline & \multicolumn{2}{|c|}{ Plant height $(\mathrm{cm})$} & \multicolumn{2}{|c|}{ No. of branches/p } & \multicolumn{2}{|c|}{ Leaf area $\left(\mathrm{cm}^{2}\right)$} \\
\hline & $1^{\text {st }}$ Cut & $2^{\text {nd }}$ Cut & $1^{\text {st }}$ Cut & $2^{\text {nd }}$ Cut & $1^{\text {st }}$ Cut & $2^{\text {nd }} \mathrm{Cut}$ \\
\hline Control & 40.21 & 34.25 & 11.20 & 21.54 & 2.00 & 2.10 \\
\hline Humic acid $1.0 \mathrm{~g} / \mathrm{L}$ & 44.11 & 37.25 & 11.50 & 25.22 & 2.00 & 2.35 \\
\hline Humic acid $1.5 \mathrm{~g} / \mathrm{L}$ & 50.24 & 42.31 & 15.34 & 31.47 & 2.70 & 3.00 \\
\hline Humic acid $2.0 \mathrm{~g} / \mathrm{L}$ & 54.31 & 45.34 & 17.85 & 39.25 & 3.27 & 3.72 \\
\hline Potassium benzoate $1.00 \mathrm{~g} / \mathrm{L}$ & 40.57 & 35.33 & 11.00 & 22.64 & 2.00 & 2.25 \\
\hline Potassium benzoate $1.5 \mathrm{~g} / \mathrm{L}$ & 42.81 & 38.56 & 14.01 & 29.38 & 2.66 & 2.80 \\
\hline Potassium benzoate $2.0 \mathrm{~g} / \mathrm{L}$ & 45.65 & 41.84 & 16.35 & 34.17 & 2.37 & 2.59 \\
\hline Salicylic acid $1.00 \mathrm{~g} / \mathrm{L}$ & 42.38 & 37.38 & 11.30 & 22.00 & 2.00 & 2.31 \\
\hline Salicylic acid $1.5 \mathrm{~g} / \mathrm{L}$ & 46.33 & 40.25 & 13.05 & 28.61 & 3.55 & 3.82 \\
\hline Salicylic acid $2.0 \mathrm{~g} / \mathrm{L}$ & 51.34 & 43.57 & 13.75 & 31.84 & 3.90 & 3.95 \\
\hline LSD at: 0.05 & 4.72 & 4.88 & 4.04 & 4.76 & 1.29 & 1.54 \\
\hline \multirow{3}{*}{ Treatments } & \multicolumn{6}{|c|}{ Second season 2018} \\
\hline & \multicolumn{2}{|c|}{ Plant height $(\mathrm{cm})$} & \multicolumn{2}{|c|}{ No. of branches/P } & \multicolumn{2}{|c|}{ Leaf area $\left(\mathrm{cm}^{2}\right)$} \\
\hline & $1^{\text {st }}$ Cut & $2^{\text {nd }}$ Cut & $1^{\text {st }}$ Cut & $2^{\text {nd }}$ Cut & $1^{\text {st }}$ Cut & $2^{\text {nd }}$ Cut \\
\hline Control & 39.70 & 33.78 & 10.95 & 22.33 & 1.85 & 2.20 \\
\hline Humic acid $1.0 \mathrm{~g} / \mathrm{L}$ & 45.22 & 38.45 & 12.47 & 26.21 & 2.15 & 2.51 \\
\hline Humic acid $1.5 \mathrm{~g} / \mathrm{L}$ & 51.30 & 43.11 & 14.78 & 32.27 & 2.80 & 3.60 \\
\hline Humic acid $2.0 \mathrm{~g} / \mathrm{L}$ & 53.78 & 46.21 & 17.21 & 38.14 & 3.79 & 3.81 \\
\hline Potassium benzoate $1.00 \mathrm{~g} / \mathrm{L}$ & 41.24 & 35.79 & 11.94 & 22.45 & 2.11 & 2.29 \\
\hline Potassium benzoate $1.5 \mathrm{~g} / \mathrm{L}$ & 43.81 & 39.55 & 14.02 & 30.11 & 2.79 & 2.88 \\
\hline Potassium benzoate $2.0 \mathrm{~g} / \mathrm{L}$ & 46.51 & 42.35 & 16.00 & 35.36 & 2.50 & 2.74 \\
\hline Salicylic acid $1.00 \mathrm{~g} / \mathrm{L}$ & 42.71 & 38.76 & 11.42 & 22.11 & 2.18 & 2.66 \\
\hline Salicylic acid $1.5 \mathrm{~g} / \mathrm{L}$ & 47.42 & 41.42 & 12.99 & 27.43 & 3.01 & 3.80 \\
\hline Salicylic acid $2.0 \mathrm{~g} / \mathrm{L}$ & 52.65 & 44.31 & 13.81 & 32.01 & 3.80 & 3.85 \\
\hline LSD at: $5 \%$ & 4.04 & 5.23 & 2.40 & 4.39 & 1.40 & 1.44 \\
\hline
\end{tabular}




\section{2 Effect on leaf area $\left(\mathrm{cm}^{2}\right)$}

The results presented in Tables (3) showed that leaf area $\left(\mathrm{cm}^{2}\right)$ of marjoram was increased by different foliar fertilization with humic acid and salicylic acid in the $1^{\text {st }}$ and $2^{\text {nd }}$ cuts in both seasons, the higher rate $(2.0 \mathrm{~g} / \mathrm{L})$ of salicylic acid gave the largest significantly leaf area (3.90 and $\left.3.95 \mathrm{~cm}^{2}\right)$ and $\left(3.80\right.$ and $\left.3.85 \mathrm{~cm}^{2}\right)$ in both cuts in the first and second seasons, respectively), compared with control plants (2.00 and $2.10 \mathrm{~cm}^{2}$ ) and (1.85 and $2.20 \mathrm{~cm}^{2}$ ). Mady (2009) two concentrations of SA at 100 and $200 \mathrm{ppm}$ increased leaf area of tomato, which is in line with the results of the present study. The effect of humic acid had similar results of SA. The results of the present investigations are in close agreement also with the findings of Moshtaghi et al., (2011) and Azad et al., (2014) that reported that, the foliar application of humic acid $(\mathrm{Ha})$ individually increased the leaf areas of olive more than untreated plants.

As for as, the effect of potassium benzoate on the leaf area $\left(\mathrm{cm}^{2}\right)$, data showed that, no significant effect of $\mathrm{Pb}$. on the leaf area in both seasons. The highest values (2.66 and $\left.2.50 \mathrm{~cm}^{2}\right)$ and $\left(2.79\right.$ and $\left.2.88 \mathrm{~cm}^{2}\right)$ were obtained from plants applied with $1.5 \mathrm{~g} / \mathrm{L}$. The same results nearly were obtained by Serafimov and Golubinova (2015) on Lactuca sativa L.

\section{II.3 Fresh and dry weights of herb/plant}

Regarding the effect of different foliar fertilization on fresh and dry weights of herb, the data in Tables (4) indicate that application of humic acid at a the rate of 2.0 $\mathrm{g} / \mathrm{L}$ to marjoram plants gave significantly increased in fresh and dry weighs compared with untreated plants or other treatments (184.35 and $216.34 \mathrm{~g} / \mathrm{plant})$ and (179.78 and $220.41 \mathrm{~g} /$ plant) for fresh weight in the $1^{\text {st }}$ and $2^{\text {nd }}$ cuts in the two seasons respectively, and (44.28 and $76.25 \mathrm{~g} /$ plant) and (43.45 and $78.52 \mathrm{~g} / \mathrm{plant})$ for dry weight in the first and second cuts in both seasons, respectively, followed by (170.51 and $210.17 \mathrm{~g} /$ plant) and (169.85 and $212.41 \mathrm{~g} /$ plant) for fresh weight that obtained from plants treated with salicylic acid at $2.0 \mathrm{~g} / \mathrm{L}$ in the two cuts in both seasons, respectively and (41.55 and $70.33 \mathrm{~g} /$ plant) and (42.54 and $71.29 \mathrm{~g} /$ plant) dry weight in the first and second cuts in the two seasons, respectively. Moreover, fresh and dry weights of plant treated with potassium benzoate, showed the same trend. These finding are in agreement with those of (Nia, et al., (2014). Who reported that humic acid application of $\mathrm{HA}$ at $1.5 \mathrm{l} / \mathrm{ha}$, gave the highest fresh and dry weight in Rosmarinus officinalis.

\section{II.4 Essential oil \% and oil yield per plant (ml)}

Concerning the effect of foliar fertilization's treatments on the percentage of essential oils contents and oil yield/plant ( $\mathrm{ml}$ ) of marjoram plants. Data in Table (4) showed that, all the foliar treatments increased the percentage of essential oils 
contents and oil yield/plant $(\mathrm{ml})$ comparing with the untreated plants (control). It is clear that highly significant differences occurred between the percentage of essential oils contents and oil 's production/plant $(\mathrm{ml})$ produced by plants treated by salicylic acid at $2.0 \mathrm{~g} / \mathrm{L}(1.89$ and $1.95 \%)$ and $(1.88$ and $1.96 \%)$ in the 1st and 2nd cuts during both seasons, respectively. Similar increases in the on the percentage of essential oils contents and oil yield/plant $(\mathrm{ml})$ as a result of salicylic acid or humic acid treatments were reported by Khazaie et al., (2011) who mentioned that, the using of concentrations from 0 to $300 \mathrm{ml} / \mathrm{L}$ humic acid gave highest production of total essential oil of hyssop plants also Abdol Rahman et al., (2013) on cumin and Farhood et al., (2017) noticed that coriander plants treated with salicylic acid had higher seed oil content and yield compared with untreated plants.

Table 4. Effect of using some phenolic chelate compounds on fresh and dry weight (g)/ plant, percentage of essential oils contents and oil yield /plant ( $\mathrm{ml}$ ) of marjoram (Majorana hortensis $\mathrm{L}$ ) plants of two cuts during two seasons 2017 and 2018.

\begin{tabular}{|c|c|c|c|c|c|c|c|c|}
\hline \multirow{3}{*}{ Treatments } & \multicolumn{8}{|c|}{ First season 2017} \\
\hline & \multicolumn{2}{|c|}{ Fresh weight (g) } & \multicolumn{2}{|c|}{ Dry weight (g) } & \multicolumn{2}{|c|}{ Essential oil \% } & \multicolumn{2}{|c|}{$\begin{array}{l}\text { Oil yield/plant } \\
(\mathrm{ml})\end{array}$} \\
\hline & $\begin{array}{l}1^{\text {st }} \\
\text { Cut }\end{array}$ & $2^{\text {nd }}$ & $\begin{array}{l}1^{\text {st }} \\
\text { Cut }\end{array}$ & $\begin{array}{l}2^{\text {nd }} \\
\text { Cut }\end{array}$ & $\begin{array}{l}1^{\text {st }} \\
\text { Cut }\end{array}$ & $2^{\text {nd }}$ & $\begin{array}{l}1^{\text {st }} \\
\text { Cut }\end{array}$ & $\begin{array}{l}2^{\text {nd }} \\
\text { Cut }\end{array}$ \\
\hline Control & 136.24 & 171.55 & 30.22 & 57.31 & 1.04 & 1.03 & 2.00 & 2.80 \\
\hline Humic acid $1.0 \mathrm{~g} / \mathrm{L}$ & 151.11 & 185.41 & 35.22 & 61.22 & 1.54 & 1.65 & 2.33 & 3.06 \\
\hline Humic acid $1.5 \mathrm{~g} / \mathrm{L}$ & 160.28 & 197.28 & 36.25 & 69.33 & 1.55 & 1.67 & 2.48 & 3.29 \\
\hline Humic acid $2.0 \mathrm{~g} / \mathrm{L}$ & 184.35 & 216.34 & 44.28 & 76.25 & 1.60 & 1.75 & 2.95 & 3.79 \\
\hline $\begin{array}{l}\text { Potassium benzoate } 1.00 \\
\mathrm{~g} / \mathrm{L}\end{array}$ & 136.58 & 173.84 & 30.56 & 58.00 & 1.00 & 1.00 & 2.10 & 2.03 \\
\hline Potassium benzoate $1.5 \mathrm{~g} / \mathrm{L}$ & 143.35 & 179.63 & 32.47 & 58.22 & 1.54 & 1.63 & 2.21 & 2.93 \\
\hline Potassium benzoate $2.0 \mathrm{~g} / \mathrm{L}$ & 162.87 & 205.84 & 38.61 & 66.38 & 1.80 & 1.81 & 2.93 & 3.73 \\
\hline Salicylic acid $1.0 \mathrm{~g} / \mathrm{L}$ & 140.28 & 179.58 & 31.54 & 60.84 & 1.77 & 1.70 & 2.48 & 3.05 \\
\hline Salicylic acid $1.5 \mathrm{~g} / \mathrm{L}$ & 146.51 & 183.57 & 34.81 & 65.64 & 1.86 & 1.80 & 2.73 & 3.30 \\
\hline Salicylic acid $2.0 \mathrm{~g} / \mathrm{L}$ & 170.51 & 210.17 & 41.55 & 70.33 & 1.89 & 1.95 & 3.22 & 4.10 \\
\hline LSD at $5 \%$ & 8.27 & 9.04 & 3.01 & 4.86 & 0.18 & 0.19 & 0.34 & 0.39 \\
\hline \multirow{3}{*}{ Treatments } & \multicolumn{8}{|c|}{ Second season 2018} \\
\hline & \multicolumn{2}{|c|}{ Fresh weight (g) } & \multicolumn{2}{|c|}{ Dry weight (g) } & \multicolumn{2}{|c|}{ Essential oil \% } & \multicolumn{2}{|c|}{$\begin{array}{l}\text { Oil yield/plant } \\
(\mathrm{ml})\end{array}$} \\
\hline & $\begin{array}{l}1^{\text {st }} \\
\text { Cut }\end{array}$ & $\begin{array}{l}2^{\text {nd }} \\
\text { Cut }\end{array}$ & $\begin{array}{l}1^{\text {st }} \\
\text { Cut }\end{array}$ & $\begin{array}{l}2^{\text {nd }} \\
\text { Cut }\end{array}$ & $\begin{array}{l}1^{\text {st }} \\
\text { Cut }\end{array}$ & $\begin{array}{l}2^{\text {nd }} \\
\text { Cut }\end{array}$ & $\begin{array}{l}1^{\text {st }} \\
\text { Cut }\end{array}$ & $\begin{array}{l}2^{\text {nd }} \\
\text { Cut }\end{array}$ \\
\hline Control & 140.10 & 175.20 & 31.47 & 53.12 & 1.04 & 1.09 & 2.07 & 2.02 \\
\hline Humic acid $1.0 \mathrm{~g} / \mathrm{L}$ & 155.35 & 190.11 & 36.54 & 62.11 & 1.50 & 1.66 & 2.33 & 3.16 \\
\hline Humic acid $1.5 \mathrm{~g} / \mathrm{L}$ & 159.80 & 200.30 & 37.22 & 67.54 & 1.53 & 1.68 & 2.44 & 3.37 \\
\hline Humic acid $2.0 \mathrm{~g} / \mathrm{L}$ & 179.78 & 220.41 & 43.45 & 78.52 & 1.61 & 1.77 & 2.89 & 3.90 \\
\hline $\begin{array}{l}\text { Potassium benzoate } 1.00 \\
\mathrm{~g} / \mathrm{L}\end{array}$ & 141.00 & 177.31 & 31.48 & 53.22 & 1.48 & 1.64 & 2.09 & 2.91 \\
\hline Potassium benzoate $1.5 \mathrm{~g} / \mathrm{L}$ & 145.42 & 180.21 & 33.89 & 59.14 & 1.51 & 1.65 & 2.20 & 2.97 \\
\hline Potassium benzoate $2.0 \mathrm{~g} / \mathrm{L}$ & 166.35 & 207.35 & 39.62 & 68.54 & 1.79 & 1.79 & 2.98 & 3.71 \\
\hline Salicylic acid $1.0 \mathrm{~g} / \mathrm{L}$ & 143.50 & 180.25 & 32.54 & 56.71 & 1.66 & 1.71 & 2.38 & 3.08 \\
\hline Salicylic acid $1.5 \mathrm{~g} / \mathrm{L}$ & 147.20 & 185.20 & 35.22 & 61.68 & 1.75 & 1.82 & 2.58 & 3.37 \\
\hline Salicylic acid $2.0 \mathrm{~g} / \mathrm{L}$ & 169.85 & 212.41 & 42.54 & 71.29 & 1.88 & 1.96 & 3.21 & 4.16 \\
\hline LSD at: 0.05 & 6.64 & 7.55 & 3.77 & 4.05 & 0.19 & 0.21 & 0.41 & 0.42 \\
\hline
\end{tabular}




\section{II.5- Essential oil composition}

The effect of different foliar fertilization of humic acid, potassium benzoate and salicylic acid with different constitutions on oil composition shown in Table (5). Thirteen compounds, accounting for more than $90.83 \%$ of the total volatiles in most marjoram samples were detected and identified. It was clear that, Terpine-4-ol was the most abundant compound in all analyzed oils, followed by Linalyl acetate, $\beta$ Phylanderene, and Sabinene. (Ostas et al., (2001). The highest percentage of Terpine-4-ol (28.4 \%) was obtained from using humic acid at $2 \mathrm{~g} / \mathrm{l}$. Similar results are in agreement with EL-Khateeb et al., (2017) GLC analysis indicated that essential oil extracted from marjoram plants treated, humic acid at high level $(5 \mathrm{ml} / \mathrm{l})$ and were found to be rich in cis sabinene hydrate, whereas terpinen-4-ol was found was found to be rich in oil of plants treated with humic acid at $2.5 \mathrm{ml} / \mathrm{l}$. to be rich in oil of plants treated with humic acid at $2.5 \mathrm{ml} / \mathrm{l}$ or brassinolide at $50 \mathrm{ppm}$.

Table 5. Effect of using some phenolic chelate compounds on chemical composition of marjoram oil of the $2^{\text {nd }}$ cut during second season 2018.

\begin{tabular}{|l|l|l|l|l|l|l|l|l|l|l|}
\hline \multirow{2}{*}{ Compounds \% } & \multicolumn{9}{|c|}{ Treatments } \\
\cline { 2 - 13 } & Contro & Ha1 & Ha2 & Ha3 & Pb1 & Pb2 & Pb3 & Sa1 & Sa2 & Sa3 \\
\hline$\propto$-Pinene & 0.57 & 1.71 & 1.55 & 1.39 & 1.21 & 1.33 & 1.37 & 1.40 & 1.40 & 1.80 \\
\hline Sabinene & 6.45 & 9.51 & 8.55 & 9.99 & 7.55 & 8.12 & 7.97 & 8.90 & 8.78 & 8.88 \\
\hline Myrecene & 2.90 & 2.78 & 2.36 & 2.74 & 2.25 & 2.33 & 2.50 & 2.15 & 2.55 & 2.46 \\
\hline$\propto$-Terpinene & 3.55 & 4.98 & 5.11 & 5.30 & 6.22 & 6.80 & 6.52 & 6.80 & 6.80 & 6.65 \\
\hline$\propto$ - & 1.29 & 0.29 & 1.30 & 1.50 & 1.44 & 1.21 & 1.58 & 1.64 & 1.77 & 1.70 \\
\hline$\beta$ Phylanderene & 9.25 & 10.0 & 10.22 & 10.2 & 10.00 & 10.00 & 10.2 & 10.45 & 10.4 & 10.38 \\
\hline Limonene & 2.05 & 1.88 & 2.55 & 2.33 & 2.57 & 2.2 .6 & 2.61 & 2.80 & 2.90 & 2.76 \\
\hline Linalool & 4.85 & 2.29 & 5.00 & 5.72 & 6.22 & 6.21 & 7.35 & 6.55 & 7.80 & 7.70 \\
\hline Linalyl acetate & 12.79 & 16.4 & 17.2 & 16.9 & 11.55 & 11.5 & 10.4 & 17.50 & 17.8 & 17.88 \\
\hline Terpine-4-ol & 26.46 & 26.2 & 27.85 & 28.4 & 20.1 & 21.55 & 24.8 & 22.30 & 23.4 & 25.51 \\
\hline Thymol & 1.00 & 0.89 & 1.00 & 0.90 & 0.78 & 0.68 & 0.77 & 0.88 & 0.88 & 0.76 \\
\hline$\propto-$-Terpineol & 3.55 & 3.01 & 3.00 & 2.90 & 3.33 & 3.50 & 3.41 & 4.11 & 3.70 & 3.90 \\
\hline$\beta-$ & 3.01 & 2.47 & 1.70 & 2.00 & 1.55 & 1.44 & 1.97 & 1.01 & 0.96 & 0.45 \\
\hline Total & 77.72 & 82.5 & 87.39 & 90.27 & 74.77 & 74.67 & 81.4 & 86.49 & 89.3 & 90.83 \\
\hline
\end{tabular}

$\mathrm{Ha}=$ Humic acid

$\mathrm{Pb}=$ Potassium benzoate

Sa $=$ Salicylic acid

\section{II.6- Percentages of Nitrogen, Phosphorous and Potassium (K) contents}

The effect of different foliar fertilization treatments on the content of nitrogen, phosphorous and potassium percentage of marjoram leaves in the two seasons are presented in Table (6), in general, the high amount of humic acid of $2.0 \mathrm{~g} / \mathrm{l}$ was the most effective treatment for increasing percentages of $\mathrm{N}$ and $\mathrm{P}$ contents and of marjoram shoot (giving, 2.48, $0.56 \%)$ and $(2.44,0.65 \%)$ of $\mathrm{N}$ and $\mathrm{P}$ contents in the two seasons, respectively while the highest percentage of $\mathrm{K}$ (2.25 
and $2.30 \%$ ) was obtained from plants treated with potassium benzoate at $2.0 \mathrm{~g} / \mathrm{L}$ compared with control in both seasons, respectively. The results of the present investigations are in close agreement with the findings El-Khateeb et al., (2010) on Calia secundiflora plants.

Concerning the effect salicylic acid, data in Table (6), showed that significant increases in $\mathrm{N}, \mathrm{P}$ and $\mathrm{K}$ percentages were noticed during the two tested seasons under the effect for salicylic acid applications. Using salicylic acid at $2.0 \mathrm{~g} / \mathrm{l}$ was the best treatment for enhancing $\mathrm{N}, \mathrm{P}$ and $\mathrm{K}$ percentages on shoots. The increases in $\mathrm{N}, \mathrm{P}$ and $\mathrm{K}$ percentages were recorded in the two seasons as a result of the different foliar fertilization rates of SA are in agreement with the findings of Muhal et al., (2014) reported that, foliar spray of SA significantly influenced $\mathrm{N}$ and $\mathrm{P}$ uptake of Brassica species.

Table 6. Effect of using some phenolic chelate compounds on N, P and K contents of marjoram (Majorana hortensis L) plants during two seasons 2017 and 2018.

\begin{tabular}{|l|c|c|c|c|c|c|}
\hline \multirow{2}{*}{ Treatments } & \multicolumn{5}{|c|}{$\mathrm{N}, \mathrm{P}$ and K contents (\%) } \\
\cline { 2 - 7 } & \multicolumn{3}{|c|}{ First season 2017} & \multicolumn{2}{c|}{ Second season 2018} \\
\cline { 2 - 7 } & $\mathrm{N} \%$ & $\mathrm{P} \%$ & $\mathrm{~K} \%$ & $\mathrm{~N} \%$ & $\mathrm{P} \%$ & $\mathrm{~K} \%$ \\
\hline Control & 2.00 & 0.23 & 1.68 & 2.05 & 0.27 & 1.74 \\
\hline Humic acid 1.0g/L & 2.10 & 0.31 & 1.53 & 2.20 & 0.40 & 1.79 \\
\hline Humic acid $1.5 \mathrm{~g} / \mathrm{L}$ & 2.21 & 0.35 & 1.65 & 2.31 & 0.47 & 1.85 \\
\hline Humic acid $2.0 \mathrm{~g} / \mathrm{L}$ & 2.48 & 0.56 & 1.88 & 2.44 & 0.65 & 1.95 \\
\hline Potassium benzoate $1.0 \mathrm{~g} / \mathrm{L}$ & 2.00 & 0.25 & 1.80 & 2.10 & 0.27 & 2.05 \\
\hline Potassium benzoate $1.5 \mathrm{~g} / \mathrm{L}$ & 2.00 & 0.25 & 1.95 & 2.14 & 0.33 & 2.00 \\
\hline Potassium benzoate $2.0 \mathrm{~g} / \mathrm{L}$ & 2.25 & 0.34 & 2.25 & 2.19 & 0.48 & 2.30 \\
\hline Salicylic acid $1.00 \mathrm{~g} / \mathrm{L}$ & 2.02 & 0.25 & 1.68 & 2.12 & 0.29 & 1.75 \\
\hline Salicylic acid $1.5 \mathrm{~g} / \mathrm{L}$ & 2.25 & 0.28 & 1.70 & 2.18 & 0.29 & 1.79 \\
\hline Salicylic acid $2.0 \mathrm{~g} / \mathrm{L}$ & 2.31 & 0.39 & 1.75 & 2.35 & 0.42 & 1.81 \\
\hline LSD at: 0.05 & 0.22 & 0.07 & 0.17 & 0.26 & 0.14 & 0.21 \\
\hline
\end{tabular}

\section{CONCLUSION}

The foliar fertilization by different concentrations of salicylic acid, potassium benzoate, and humic acid treatments an integrated system to reduce the infestation percent of Aphis gossypii, Thrips tabaci, and Tetranychus urticae and increasing plant growth, yield, and essential oil of marjoram.

\section{REFERENCES}

1. Abdol Rahman Rahimi; Asad Rokhzadi and Sheno Amini. 2013. Effect of salicylic acid and methyl jasmonate on growth and secondary metabolites in Cuminum cyminum L. Journal of Biodiversity and Environmental Sciences JBES. Vol. 3, No. 12, p. 140-149, 2013. 
2. Azad, A.M.; Ibrahim Z. R. and Abdurrahman A. S. 2014. Effect of foliar spray of humic acid, ascorbic acid, cultivars and their Interactions on growth of olive (Olea European L.) transplants cvs. Khithairy and Sorany. Journal of Agriculture and Veterinary Science, 7(4), 18-30.

3. Bayat H.; Alirezaie M. and H. Neamati. 2012. Impact of exogenous salicylic acid on growth and ornamental characteristics of calendula (Calendula officinalis L.) under salinity stress. J. Stress Physiol. Biochem. 8:258-267.

4. Bodenhausen N, Reymond P. 2007. Signaling pathway controlling induced resistance to insect herbivores in Arabidopsis. Mol plant Microbe interact 20:1406-1420.

5. Bremner JM, Mulvaney CS. 1982. Total nitrogen. In Page, ALRH Miller and DR Keeney (Eds) Methods of Soils Analysis Part 2 Amer. Soc. Agron. Madson WI. U. S. A., pp.595-624.

6. British Pharmacopoeia. 2002. British Approved Names. A Dictionary of Drug Names for Regulatory Use in the UK. Stationary Office Press, London, UK.

7. Demetzos C. and Perdetzoglou DK. 2001. Composition antimicrobial studies of the oils of origanum calcaratum Juss. And O. scabrum Boiss. Et Heldr. From Greece, J.Essential Oil Res., 13: 460-462.

8. El-Khateeb ,M.A.; A. A Nasr; A.N Fahmy and A.H. Dorgham. 2010. Effect of GA3 and growth bio stimulants on growth and chemical composition of Calia secundiflora plants . Jour.of Horticultral science and ornamental plants .2(2),118124.

9. El-Khateeb M. A.; El-Attar A. B. and Nour R. M. 2017. Application of Plant Biostimulants to Improve the Biological Responses and essential oil production of marjoram (Majorana hortensis, Moench) plants. Middle East Journal of Agriculture. Research. Volume : 06(10), 928-941.

10. El-Shazly, A.M. and Hussein, K.T. 2004. Chemical analysis and biological activities of the essential oil of Teucrium leucocladum Boiss. (Lamiaceae). Biochem. Syst. and Ecology, 32(7): 665-674.

11. Eyheraguibel, B., J. Silvestre and P. Morard. 2008. Effects of humic substances derived from organic waste enhancement on the growth and mineral nutrition of maize. Biores. Technol., 99:4206-421.

12. Farhood Y.; Saeid Z. S. and Jalil S.K. 2017. Evaluation of some morphological traits and oil content of coriander seeds in response to bio-fertilizer and salicylic acid under water stress. Journal of Biodiversity and Environmental Sciences, 10, (1), 140-149, 
13. Gomez, K.A. and A.A. Gomez. 1984. Statistical Procedures for. Agricultural Research, $2^{\text {nd }}$ Edition. John Wily and Sons, New York, 680 pp.

14. Guenther, Z. and S. Joseph. 1978. Handbook Series in Chromatography. GRC Press Inc

15. Jackson ML. 1970. Soil Chemical Analysis. Prentic Hau, Englewood Cliffs, N. J.

16. Khazaie H. R.; E. Eyshi Rezaie and M. Bannayan. 2011. Application times and concentration of humic acid impact on aboveground biomass and oil production of hyssop (Hyssopus officinalis). Journal of Medicinal Plants Research Vol. 5(20), pp. 5148-5154,

17. Koul, O., Walia, S. and Dhaliwal, G. S. 2008. Essential Oils as Green Pesticides: Potential and Constraints. Biopestic. Int. 4(1): 63-84.

18. Krantev, A.; R.Yordanova,; T. Janda,.; G. Szalai, and Popova, L. 2008. Treatment with salicylic acid decreases the effect of cadmium on photosynthesis in maize plants. Journal of Plant Physiology, 165(9): 920-931.

19. Mady. 2009. Effect of foliar application with salicylic acid and vitamin of tomato (Lycopersicon esculentum, Mill.) plants. J. Agric. Sci. Mansoura Univ., 34 (6): $6735-6746$.

20. Mahmoud F. Mahmoud and Mahfouz H. M. 2015. Effects of salicylic acid elicitor against aphids on wheat and detection of infestation using infrared thermal imaging technique in Ismailia, Egypt (*mfaragm@hotmail.com; mfaragm@agr.suez.edu.eg) Received Pestic. Phytomed. (Belgrade), 30(2), 2015, 91-97, March 17, 2015.

21. Marta L. del Campo; Halitschke R.; S. Sarah M.; L. Brian P.; and André Kessler. 2013. Dietary plant phenolic improves survival of bacterial infection in Manduca sexta caterpillars. Entomol Exp. Appl. 146(3): 321-331.

22. Moshtaghi, A. E.; Jaime A. Teixeira da S. and S. Ali Reza. 2011. Effects of foliar application of humic acid and gibberellic acid on mist-rooted olive cuttings. Fruit, Vegetable and Cereal Science and Biotechnology 5 (Special Issue 2), 76-79.

23. Muhal, S.; N. S. Solanki; P. Singh and K. B. Shukla. 2014. Effect of salicylic acid on productivity and nutrient uptake of Brassica species under different planting durations. Afr. J. Agric.Vol.9 (13), pp. 1101-1106, March 2014.

24. Nardi, S., Pizzeghello, D., Muscolo, A. and Vianello, A. 2002. Physiological effects of humic substances on higher plants. J. Soil Biol. Biochem. 34: 1527-1536. 
25. Nia,F., A. Mehrafarin, E. Hadavi, and N. Badi. 2014.The Influences ofbiostimulators compounds on growth traits and essential oil content of rosemary (Rosmarinus officinalis L.). J. Medicinal Plants.13 (51):1-12.

26. Olsen SR, Sommers LE . 1982. Phosphorus In Page, ALRH Miller and DR Keeney (Eds). Methods of Soil Analysis, Part 2- Am. Soc. Agron.Madison. WI- USA, pp. 403- 430.

27. Ostas D.; Thalia A. and Dimitrios P. 2001. School of Pharmacy, Department of Pharmacognosy, University of Athens, demetzos@galenos.pharm.uoa.

28. Pettersson C., Ephraim J. and Allard B. 1994. On the composition and properties of humic substances isolated from deep groundwater and surface waters. Org. Geochem., 21(5), 443-451.

29. Pickett, A.J., Bruce, A.J.T., Chamberlain, K., Hassanali, A., Khan, R.Z., Matthes, C.M., and Woodcock M.C. 2006. Plant volatiles yielding new ways to exploit plant defense. In M. Dicke \& W. Takken (Eds.), Chemical ecology: From gene to ecosystem (pp 161-173). Dordrecht, Netherlands: Springer.

30. Prowse, G.M.; Galloway, T.S. and Foggo, A. 2006. Insecticidal activity of garlic juice in two dipteran pests. Agric. Forest. Entomol., 8(1): 1-6.

31. Said-Al Ahl H.A.H*. El Gendy A.G. and O mer E.A. 2016. Humic acid and indole acetic Acid affect yield and essential oil of dill grown under two different locations in Egypt. J. Pharm. Sci. \& Res. Vol. 8(7), 2016, 594-606.

32. SAS Institute. 1999. SAS User's guide: Statistics SAS Inst., Cary, $N$

33. Sawada, H., I. S. Shim and K. Usui. 2006. Induction of benzoic acid 2-hydroxilase and salicylic acid biosynthesis- Modulation by salt stress factor in wheat in rice seedling. J. Plant Sci, 171, Issue. 2: 263-270.

34. Schneider-Orelli formula (Nakano et al., 1981). 1volume 97, Issue 2, February 2008, Pages 83-90.

35. Serafimov, P. M. and Golubinova I. 2015. A study of suitability of some conventional chemical preservatives and natural antimicrobial compounds in allelopathic research. Pestic. Phytomed. (Belgrade), 30(4), 233-241.

36. Stevens J. and Senaratna T. 2006. Salicylic acid induces salinity tolerance in tomato (Lycopersicon esculentum cv.Roma): associated changes in gas exchange, water relations and membrane stabilization. Plant Growth Regul, 49:77-83.

37. Zhou, Zh.; Sh., Guo, K.; Abdou Elbaz, A. and Yang Zh. M. 2009. Salicylic acid alleviates mercury toxicity by preventing oxidative stress in roots of Medicago sativa, Environmental and Experimental Botany, 65: 27-34. 
تأثير التسميا ببعض المركبات الفينولية وحامض الهيومك على حساسية البردقوش للإصابة بالحشر ات و الأكاروس و الصفات التباتية

خالد عبد المنعم همام 1 ، عفاف محمد صالح الروبى (2 ، منى ابراهيم عمار (2)

$$
\text { 2. } 1 \text { معهد بحوث البساتبن - مركز البحوث الزراعية }
$$

أجريت الدراسة الحالية خلال موسمين متتاليين عام 2017 و 2018 بمحافظة الجيزة ،

لار اسة تأثثر بعض المركبات الفينولية (حامض الهيوميك ، بنزوات البوتاسيوم وحمض الساليسيليك)

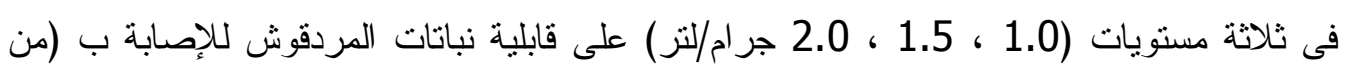

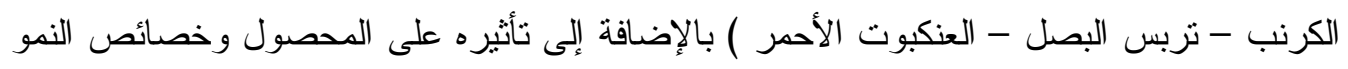

$$
\text { ومحتوياتة من الزيوت الأساسية. }
$$

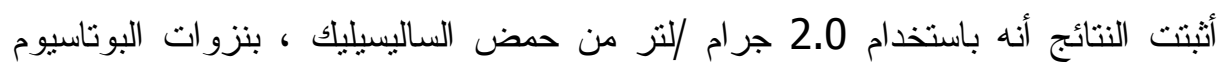
وحامض الهيومك كسماد للنبات البردقوش ، نسبب في ظهور خفض معنوي واضح في الإصابة

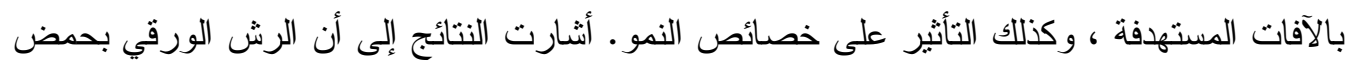

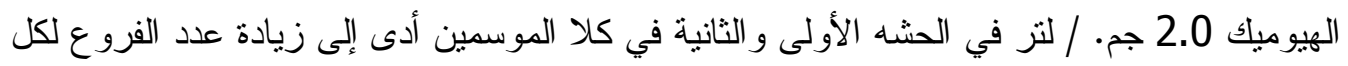

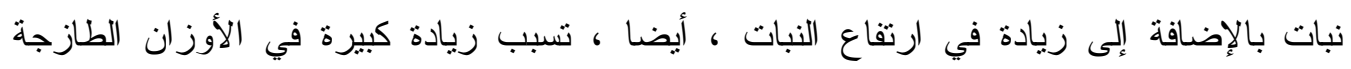

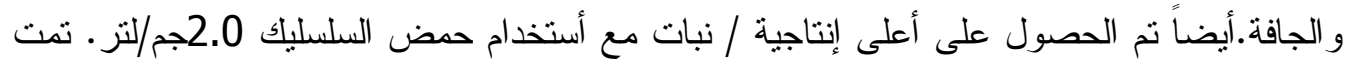

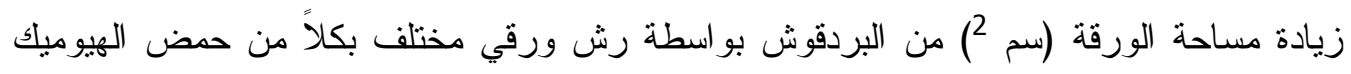

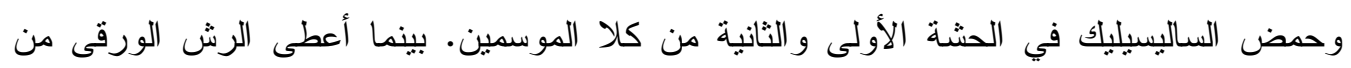
بنزو ات البوتاسيوم نتائج اقل كفاءة. 
